\title{
HYDROGEOLOGICAL CHARACTERIZATION OF THE SALINAS- LOS HOYOS EVAPORITIC KARST (MALAGA PROVINCE, S SPAIN) USING TOPOGRAPHIC, HYDRODYNAMIC, HYDROCHEMICAL AND ISOTOPIC METHODS
}

\author{
HIDROGEOLOŠKA OPREDELITEV EVAPORITNEGA KRASA NA \\ OBMOČJU SALINAS-LOS HOYOS (PROVINCA MALAGA NA JUGU \\ ŠPANIJE) Z UPORABO TOPOGRAFSKIH, HIDRODINAMIČNIH, \\ HIDROKEMIČNIH IN IZOTOPSKIH METOD
}

\author{
José Manuel GIL-MÁRQUEZ ${ }^{1, *}$, Matías MUDARRA ${ }^{1}$, Bartolomé ANDREO ${ }^{1}$, Luis LINARES ${ }^{2}$, \\ Francisco CARRASCO ${ }^{1} \&$ José BENAVENTE ${ }^{3}$
}

\begin{abstract}
UDC 551.444(460.356)

José Manuel Gil-Márquez, Matías Mudarra, Bartolomé Andreo, Luis Linares, Francisco Carrasco \& José Benavente: Hydrogeological characterization of the Salinas-Los Hoyos evaporitic karst (Malaga province, $S$ Spain) using topographic, hydrodynamic, hydrochemical and isotopic methods

The Salinas-Los Hoyos karst system is a geological diapiric structure formed by materials of diverse nature (clays, sandstones, evaporites, volcanic rocks, dolostones, etc.) placed between Malaga and Granada provinces (S Spain). The abundance of evaporite rocks (gypsum, anhydrite and halite) and their high solubility contribute to the development of exokarstic features (dolines, uvalas, sinkholes). Grande and Chica lakes are dolines located in the western border of the diapir that are intersected by the piezometric level. Close to the first wetland is the Aguileras spring, which is the main discharge point of the west sector of the system. To assess the wetland-spring relation and the general functioning of the system, the geomorphologic framework has been analyzed and hydrogeological controls have been performed, consisting in limnimetric and discharge logging and in situ measurements of physico-chemical parameters (EC and water temperature). Furthermore, spring, wetland and rain water samples have been taken for subsequent chemical and isotopic analysis. Preliminary results show that wetland water level and spring discharge follow a similar trend, consistently with the inertia of the system. However, their hydrochemical evolution and isotopic values differ, thus wetland-
\end{abstract}

Izvleček

UDK 551.444(460.356)

José Manuel Gil-Márquez, Matías Mudarra, Bartolomé Andreo, Luis Linares, Francisco Carrasco \& José Benavente: Hidrogeološka opredelitev evaporitnega krasa na območju Salinas-Los Hoyos (provinca Malaga na jugu Španije) z uporabo topografskih, hidrodinamičnih, hidrokemičnih in izotopskih metod

Kraški sistem Salinas-Los Hoyos je geološka struktura v obliki diapirja, ki ima pestro sestavo (gline, peščenjaki, evaporitne, magmatske in dolomitne kamnine idr.) ter se nahaja med provincama Malaga in Granada na jugu Španije. Prisotnost evaporitnih kamnin (sadra, anhidrit in halit) in njihova visoka topnost so omogočili nastanek kraških pojavov (vrtače, uvale, ponori). Jezeri Grande in Chica sta vrtači na zahodni meji diapirja, ki ju členi piezometrični nivo. V bližini prvega mokrišča najdemo izvir Aguileras, ki predstavlja pretočno točko v zahodnem sektorju sistema. Da bi bilo mogoče oceniti razmerje med mokriščem in izvirom ter splošne značilnosti delovanja tega sistema, je bila opravljena analiza oblikovanosti površja, vzpostavljene pa so bile hidrogeološke meritve. Te so obsegale meritve višine in pretoka vode ter terenske meritve fizikalno-kemijskih značilnosti (temperatura vode in specifična električna prevodnost). Za namene kemijske in izotopske analize so bili vzeti tudi vzorci izvira, mokrišča in padavinske vode. Predhodni rezultati so pokazali, da nivo vode v mokrišču in pretok izvira sledita podobnemu trendu, kar nakazuje na povezanost tega sistema. Njihov hidrokemični razvoj in izotopske vrednosti pa se razlikujejo, zato odnosa med mokriščem

\footnotetext{
${ }^{1}$ Department of Geology and Centre of Hydrogeology of the University of Malaga (CEHIUMA), 29071 Malaga, Spain, e-mail: josemgil@uma.es,mmudarra@uma.es,_andreo@uma.es, fcarrasco@uma.es

${ }^{2}$ Academy of Sciences of Malaga, C/Moratín 4 (1º-2), 29015 Malaga, Spain, e-mail: luislinares@telefonica.net

${ }^{3}$ Department of Geodynamics and Water Research Institute, University of Granada. Av. Fuente Nueva s/n, 18071 Granada, Spain, e-mail: jbenaven@ugr.es

* Corresponding author
}

Received/Prejeto: 17.03.2016 
groundwater interaction has not been fully determined. Nevertheless, present research suggests that the hydrogeological connection would be more likely during wet periods, when the water table is at higher altitude.

Key words: Evaporitic (karst) aquifer, Hydrological and hydrogeological behaviours, Natural responses, South Spain, Wetlands. in podzemno vodo ni bilo mogoče v celoti določiti. Kljub temu pričujoča raziskava nakazuje, da bi hidrogeološka povezavo lahko potrdili v namočenem obdobju, ko je gladina vode na večji nadmorski višini.

Ključne besede: evaporitni (kraški) vodonosnik, hidrološke in hidrogeološke lastnosti, naravni odziv, južna Španija, mokrišča.

\section{INTRODUCTION}

Carbonate karst aquifers have been broadly studied during the last decades, leading to significant advances in the knowledge of Karst Hydrogeology and related processes (White 1988; European Comission 1995; Drew \& Goldscheider 2007; Ford \& Williams 2007; Andreo et al. 2015). On the contrary, research on evaporite karst areas have mainly been focused on aspects related to geomorphology, karstology, natural impacts or human-induced geohazards (Forti \& Sauro 1996; Calaforra \& Pulido-Bosch 1999; Klimchouk et al. 1999; Nicod 2006; Gutiérrez et al. 2008, 2014; Iovine et al. 2010; Cooper \& Gutiérrez 2013), rather than on its hydrogeological functioning, since water resources stored in these media are normally low and of poor quality (characterized by high salinity).

At the southern sector of the Subbetic Domain of the Betic Cordillera (S Spain), there is a large outcrop made up by Upper Triassic (Keuper) clays and evaporite rocks (gypsum, anhydrite and halite), as well as blocks from other lithologies (limestones, dolostones, sandstones, etc.) of Triassic to Miocene ages (Pérez-López \& Sanz de Galdeano 1994). All these materials, termed as Chaotic Subbetic Complexes -CSC- Unit (Vera \& Martín-Algarra 2004), appear as a chaotic mega-breccia highly deformed due to the northwestwards movement of the so-called Internal Zone of the Betic Codillera and its collision with the Subbetic Domain during Miocene age (Rodríguez-Fernández et al. 2013). Low permeability and aquitard behavior have been traditionally attributed to the Triassic rocks of the CSC Unit (e.g. López-Chicano et al. 2001; Martos-Rosillo et al. 2013). However, dissolution/karstification processes affecting evaporite rocks provoke an increase in the development of secondary porosity and permeability. Thereby, unstable karst conduits and cavities are originated, whose collapses give place to subsidence phenomena and to a rapid geomorphological evolution of exokarst features: sinkholes and surface depressions (Calaforra \& PulidoBosch 1999; Gutiérrez et al. 2008). Similar processes have been described in other evaporitic karst areas of Europe (Parise \& Trocino 2005; Liguori et al. 2008; Parise et al. 2008; Iovine et al. 2010), given the abundant outcropping of evaporitic rocks in the Mediterranean basin.
The high solubility of evaporitic materials plays a notable influence on the hydrology and hydrogeology of CSC outcrops. In general, most of the exokarst features are placed in areas of gentle relief where a poorly defined drainage network exists, frequently found in watersheds dividing the main river basins. In these areas, the development of surface depressions has been enhanced by recent uplifting movements linked to diapiric or halokinetic processes (Pezzi 1977; Rodríguez-Estrella 1983; Linares 2008). Some of these endorheic depressions can be flooded temporary or even permanently, originating wetland areas and ephemeral lakes of variable size but of great environmental value (some of them are listed in the Ramsar Convention of Wetlands). In this context, groundwater flow influences the hydrological functioning of wetlands, especially when it is in connection with the piezometric level. Thus, wetlands located in relative elevated topographic positions are flooded in high water conditions whenever the water table reaches their bottom. On the contrary, during dry periods, the water table may move below the bottom of wetlands, resulting on them being dried up (Andreo et al. 2016). Consequently, surface depressions can contribute to the recharge of subjacent aquifers, even more considering the usual presence of karst swallow holes, which can become active during rainstorm. In any case, wetland areas located in these relatively higher positions do not constitute the last destination of groundwater flow, but rather the flow path is towards other wetlands or springs situated at lower altitude coinciding with the base levels for CSC outcrops.

Despite a clear dependence on the water table variations has been found in the hydrological regime of many wetlands (Almécija 1997; Rodríguez-Rodríguez et al. 2006; Gutiérrez et al. 2008; Linares 2008; Andreo et al. 2016), the hydrogeological heterogeneity detected in CSC outcrops provokes that, in several cases, it is not possible to define accurately the hydrogeological connection and the flow paths between wetlands and nearby springs. This occurs in the case-study exemplified in this work: Los Hoyos-Salinas system, a diapiric structure be- 

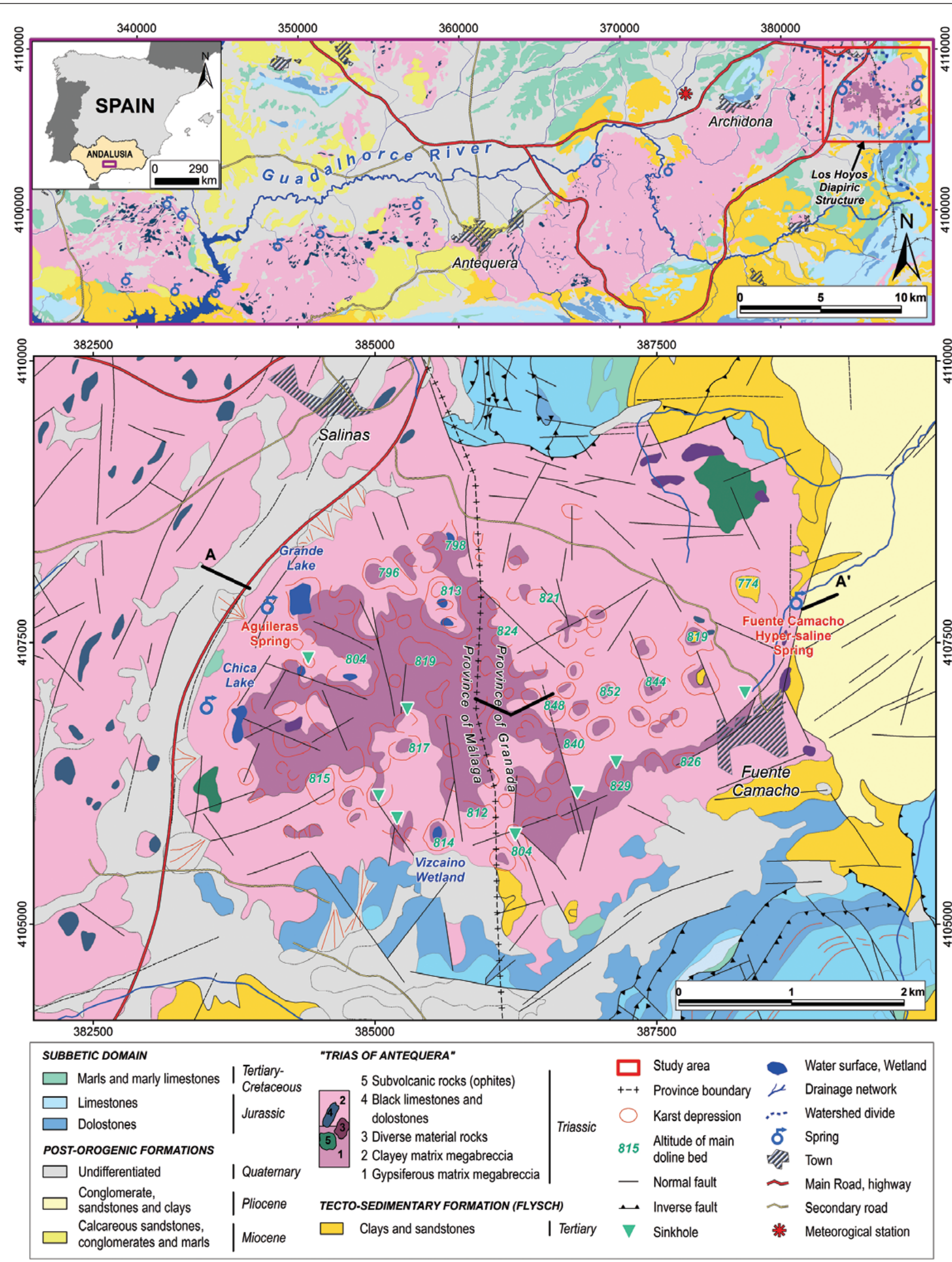

Fig. 1 : Geographical and geological setting. Modified from Carrasco et al., 2007 (above) and Pineda Velasco, 1990 (below). 
longing to the CSC Unit and located between Malaga and Granada provinces (Southern Spain, Fig. 1), where a singular evaporite-karst landscape developed. At the NW border of study area, two permanent wetlands (known as Grande and Chica lakes) occupy two endorheic depressions. Groundwater drainage in this sector takes place visibly towards the western border of the system, mainly through a spring located $250 \mathrm{~m}$ westward of Grande Lake. Although the hydrological dependence of both wetlands with groundwater seems possible (Linares 2004; Rodríguez-Rodríguez et al. 2007), the hydrogeological connection between them and the spring has not been fully determined, in spite of their proximity.

The aims of this work are to progress in the characterization of the general hydrogeological functioning of the evaporite karst systems existing within CSC materials and to advance in the determination of the wetland-spring relationship by jointly applying different approaches: topographic, hydrodynamic, hydrochemical and isotopic. With these goals, high resolution digital elevation data from Airborne LIDAR (Laser Imaging Detection and Ranging) and hydrological information from continuous record data on variations in water level and spring discharge, as well as hydrochemical and isotopic observations compiled in the pilot site (sector of Los Hoyos-Salinas, Fig. 1) during two years, have been used. This will help to better understand the hydrogeological functioning of evaporitic karst areas, taking into account their geological and geomorphological particularities, for protection, management and, if necessary, a hydrological restoration of the wetlands located in this context.

\section{SITE DESCRIPTION}

The Salinas-Los Hoyos diapirc structure is the easternmost of an extensive and elongated outcrop of CSC materials, known as "Trias of Antequera" (pink colour in Fig. 1; Peyre 1974; Calaforra \& Pulido-Bosch 1999; Sanz de Galdeano et al. 2008), with ENE-WSW direction in the northern part of the province of Malaga. The study area, of approximately $20 \mathrm{~km}^{2}$, presents an altitudinal range from 700 to $900 \mathrm{~m}$ a.s.l. Despite its low orography in comparison with the nearby reliefs, the pilot site is situated in the watershed divide between two significant rivers in Andalusia (Fig. 1): Guadalhorce River (W) and Guadalquivir River (E). The prevailing climate in the region is temperate Mediterranean, with a marked seasonal pattern in the annual distribution of precipitation. Rainfall mainly occurs in autumn, winter and, to a lesser extent, in spring time, associated with wet winds coming from the Atlantic Ocean (mean value of 90 $\mathrm{mm}$ for November and December, whereas is $3 \mathrm{~mm}$ for July). The mean historic annual precipitation is $563 \mathrm{~mm}$ (Consejería de Medio Ambiente 2005). The research period (January 2014 to January 2016) could be considered slightly dry, with an average annual precipitation of 409 $\mathrm{mm}$. Mean annual temperature is close to $16^{\circ} \mathrm{C}$ (Consejería de Medio Ambiente 2005), with relatively warm summers $\left(26.2^{\circ} \mathrm{C}\right.$ in July) and mild winters $\left(7.7^{\circ} \mathrm{C}\right.$ in January). The annual potential evapotranspiration calculated by the Thornthwaite method (Thornthwaite 1948 ) is $861 \mathrm{~mm}$, with maximum values during summer months (166 mm in July).

Geologically, CSC Unit is characterized in this area by the predominance of multi-coloured clay, sandstones and evaporitic materials (gypsum and halite). Gypsum occupies the center of the diapiric structure, showing typical massive outcrops, or as a polygenic breccia made up by gypsum fragments and little parts of clays, limestones and dolostones (Calaforra \& Pulido-Bosch, 1993). Although halite is not present at the surface, due to its high solubility, its existence in depth can be inferred from groundwater hydrochemistry of a nearby saline spring (Carrasco 1986; Calaforra 1998; Figs. 1 \& 2). The CSC rocks are highly deformed, in a chaotic way, thus it is difficult to appreciate their original stratigraphic relations. Furthermore, the halokinetic processes related to the presence of gypsum and salt at depth have caused a ground uplifting, resulting on a higher elevation of the study area (about $50 \mathrm{~m}$ ) with respect to the surrounding Plio-Quaternary materials (placed between 700 -E border- to $750 \mathrm{~m}$ a.s.l. -W border-, Fig. 2).

Karst landscape in Salinas-Los Hoyos area is characterized by the existence of a large number of dolines (of different typology), sinkholes, small surface depressions, etc. (Fig. 1). In the core of the diapir, where uplifting processes are most active, collapses, conical and cylindrical dolines (someone with small sinkholes) appear, whose bottoms are placed around $850-840 \mathrm{~m}$ a.s.l. Towards the edges of the diapiric structure, the size of dolines increases, with flat-floored bottoms, topographically placed at lower altitude (from 830 to $810 \mathrm{~m}$ a.s.l.), even lower than $800 \mathrm{~m}$ a.s.l. to northwestwards, where Grande (Fig. 3a \& b) and Chica lakes are situated (Consejería de Medio Ambiente 2005). The main axes of these large depressions tend to follow the direction of the perimeter 


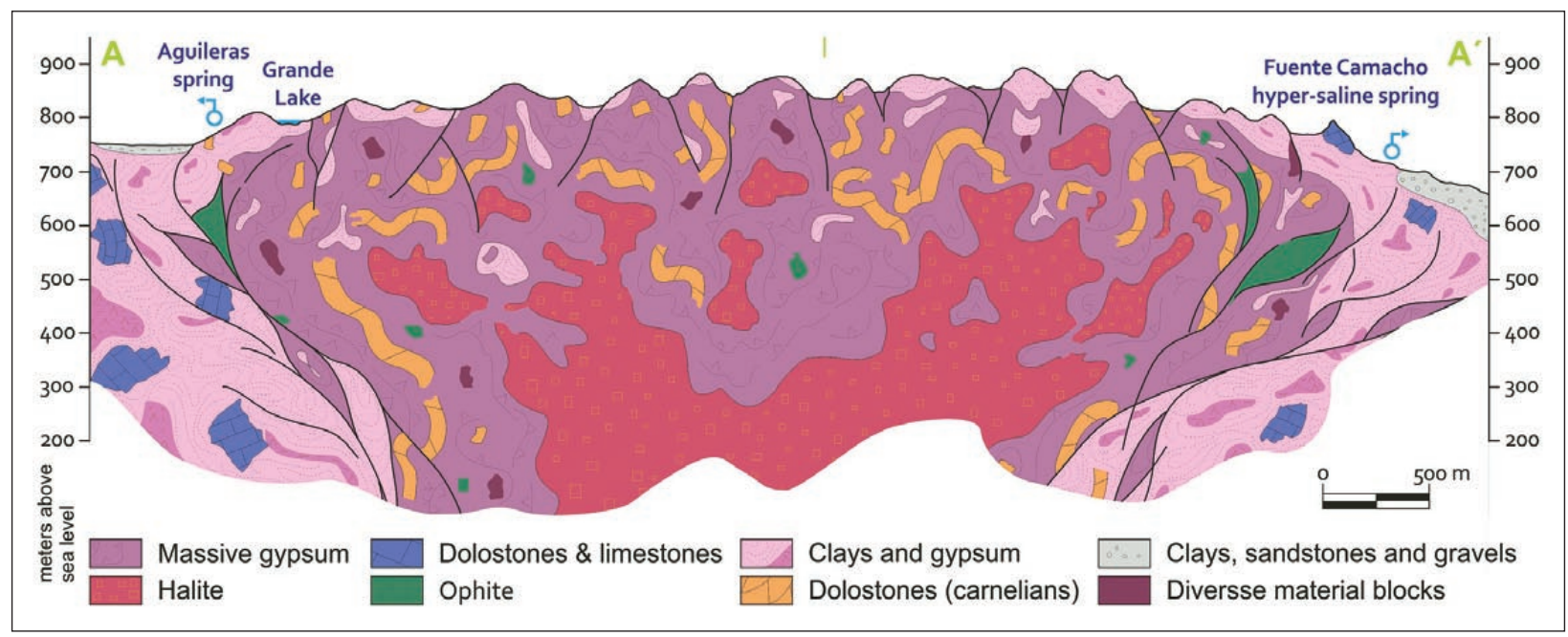

Fig. 2: Cross section of Salinas-Los Hoyos diapiric structure.

of the diapir, reflecting its notable structural influence (Calaforra \& Pulido-Bosch, 1999). The high concentrations and the diversity of karst morphologies found in a relatively small area, made the Salinas-Los Hoyos system a place of particular interest from a geomorphology and landscaping point of view.

In hydrogeological terms, the Salinas-Los Hoyos diapir constitutes a small and interesting system, well-defined by its borders (Linares 2008). Recharge takes place by diffuse infiltration of rainwater through dolines and gypsum blocks, but also by the direct infiltration of surface water into swallow holes. Discharge occurs through springs located at the borders of the diapiric structure (Figs. $1 \& 2$ ) and by water evaporation from the wetland surfaces. The most remarkable outflow point is Aguileras spring (15 1/s annual mean flow, Rodríguez-Rodríguez et al. 2007), placed at $787 \mathrm{~m}$ a.s.l. in the western sector of the system (Figs. 3c \& 4). In fact, this spring corresponds to a gallery constructed in order to use groundwater in a neighboring old flour mill. Moreover, there are also other outflow points in the system, although with low discharge rates (less than $2 \mathrm{l} / \mathrm{s}$ ), highlighting the hyper-saline spring of Fuente Camacho, placed at $705 \mathrm{~m}$ a.s.l. in the eastern border of the diapiric structure (Figs. 1 \& 2). Grande and Chica lakes, each with an approximate average surface area of $7 \mathrm{ha}$, are the most significant wetlands existing in the study area. Grande Lake is permanently flooded and reaches a maximum depth of $13.2 \mathrm{~m}$, whereas the greatest depth in Chica Lake is $8.3 \mathrm{~m}$ (Rodríguez-Rodríguez et al. 2007). The latter can
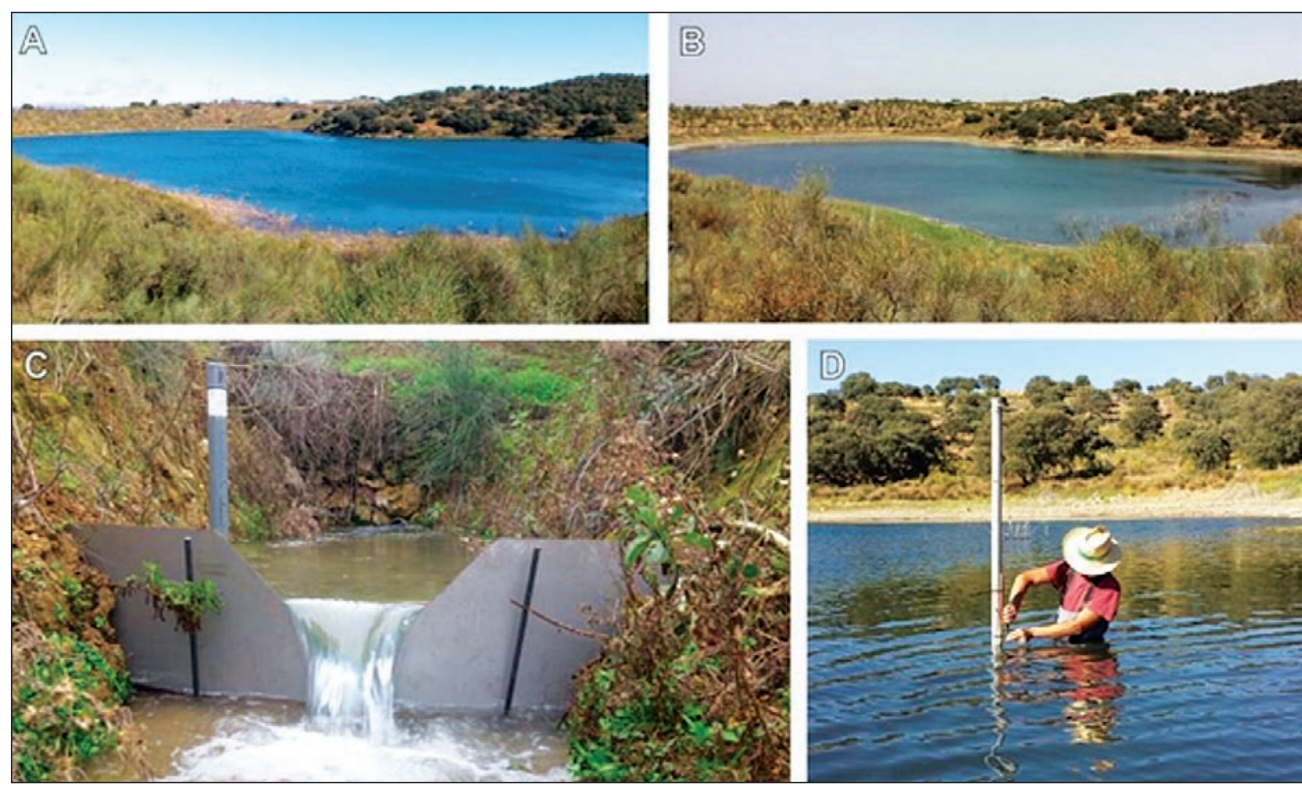

Fig. 3: Panoramic views of Grande Lake in February 2014 (a) and August 2015 (b). Gauging section in Aguileras spring, equipped with $90^{\circ} V$-notch weir and water capacitance level logger (c). Installation of water capacitance level logger in Grande Lake (d). 
occasionally become dry during some drought periods, when the phreatic level is below its bottom. Both wetlands are principally fed by groundwater and outputs are produced by evaporation, but also via infiltration towards adjacent aquifer located to the West (Andreo et al. 2016). Additionally, there are other surface depressions in the area that can be considered as seasonal wetlands, since the water table intersects periodically their bottoms. Finally, other dolines placed at higher altitude can be flooded for a short period of time after heavy rainfall events.

\section{METHODS}

From February 2014 to January 2016, hourly records of water level variations in Aguileras spring and Grande Lake (from April 2014) were acquired using Odyssey ${ }^{\circledast}$ capacitance water level probes (Figs. $3 \mathrm{c}$ and d), with a resolution of approximately $0.8 \mathrm{~mm}$. Both data-loggers were in situ calibrated before their installation, following manufacturer specifications. Water level variations were converted to continuous measurements of water surface altitude (in $\mathrm{m}$ a.s.l.), adopting identifiable points in a high resolution digital elevation model (DEM) as stable reference marks. DEM was created from Airborne LiDAR cover dataset (using GIS ArcMap $`$ v.10.2 software), performed over the study area in the summer of 2008 (Consejería de Medio Ambiente 2008). The vertical accuracy of the delivered LiDAR data was within $8.0 \mathrm{~cm}$ root mean square error (RMSE) and the LiDAR point cloud cover was acquired at a nominal point spacing of $0.5 \mathrm{~m}$. On the other hand, discharge rate evolution was obtained from continuous water level measurements applying manual discharge measurements at the spring (starting from January 2014, OTT $^{\circledast}$ C2 Flow Meter). A gauging station with a $90^{\circ} \mathrm{V}$-notch weir was equipped in Aguileras spring for continuous discharge record.
During the study period, field measurements of electrical conductivity (EC) and temperature (WTW ${ }^{\circledast}$ Cond 3310) were made at the spring water (fortnightly) and at Grande and Chica lakes (monthly) from January 2014 to January 2016 and from August 2014 to January 2016, respectively. Simultaneously to in situ measurements, water samples (totally 47 from Aguileras spring and 13 from Grande and Chica Lakes) were collected in 150-ml amber glass bottles for subsequent chemical and isotopic analysis in the laboratory. Water sampling in both lakes was carried out at approximately $0.5 \mathrm{~m}$ depth, using a 3-m extensible stick. Moreover, in November 2015, 9 vertical profiles of temperature and EC (measurements every $1 \mathrm{~m}$ ) were made along the $\mathrm{S}-\mathrm{N}$ and E-W axes of Grande Lake (Fig. 4), using a water quality multiprobe (SEBA $\left.{ }^{\circledast} \mathrm{KLL}-\mathrm{Q}\right)$. At the same time, a water sample was collected at the surface and another one at the maximum depth of each profile (for their chemical and isotopic analysis) by means of a submersible pump (Waterra ${ }^{\circledR}$ WSP-12V-3 Tempest). Finally, precipitation and air temperature were hourly recorded at a meteorological station located $10 \mathrm{~km}$ to the west $(530 \mathrm{~m}$ a.s.l., Fig. 1). A rain water capture system was emplaced near-

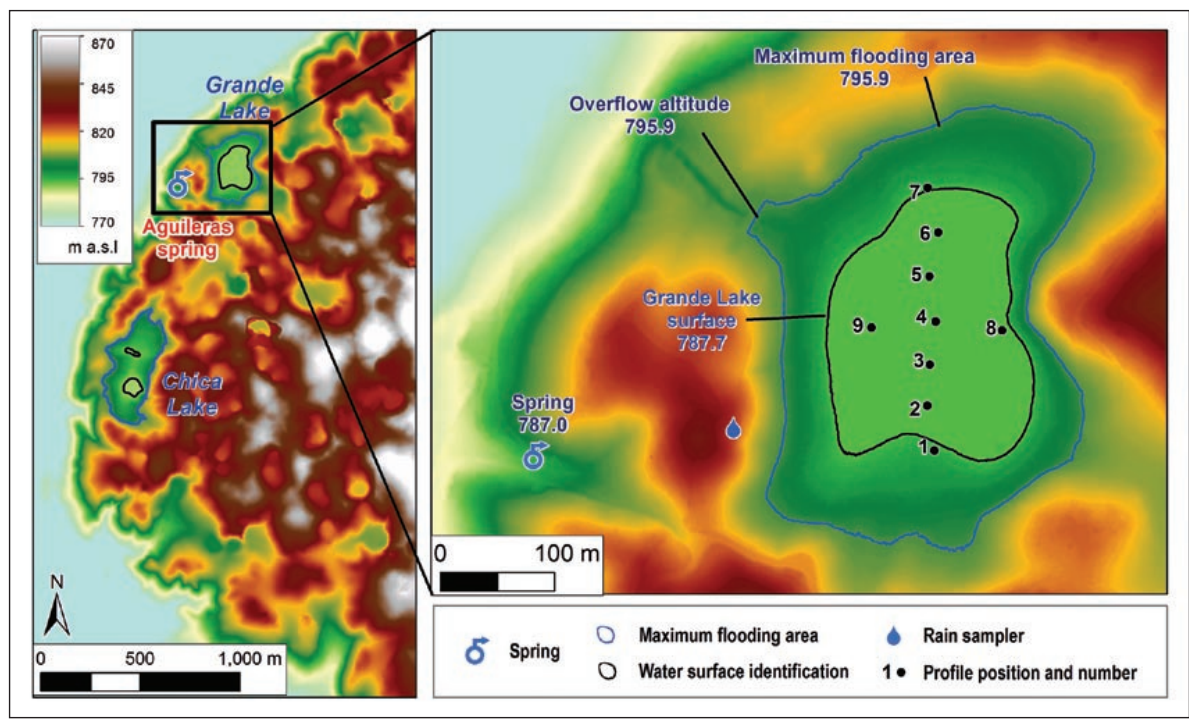

Fig. 4: Digital Elevation Model from LiDAR point dataset (Consejería de Medio Ambiente 2008) of the western sector of SalinasLos Hoyos diapir (left). Grande Lake surrounding area and schematic position of vertical profile measurements done in November 2015 (right). 
by Grande Lake for hydrochemistry and isotopic rainfall characterizations (Fig. 4).

Chemical and isotopic analyses were carried out at the Centre of Hydrogeology of the University of Malaga (CEHIUMA). Alkalinity (Alk) was determined by volumetric titration using $0.02 \mathrm{~N} \mathrm{H}_{2} \mathrm{SO}_{4}$ to $\mathrm{pH} 4.45$. The chemical analyses of the major components $\left(\mathrm{Ca} 2+, \mathrm{Mg}^{2+}\right.$, $\left.\mathrm{Na}^{+}, \mathrm{K}^{+}, \mathrm{Cl}^{-}, \mathrm{SO}_{4}^{2-}, \mathrm{NO}_{3}^{-}, \mathrm{F}^{-}, \mathrm{Br}^{-}\right)$were performed using high pressure liquid chromatography (HPLC, Metrohm ${ }^{\circ}$
792 Basic IC and Metrohm Compact 881 IC pro) with $\pm 0.1 \mathrm{mg} / \mathrm{l}$ of accuracy. Samples were diluted to $1 \mathrm{mS} / \mathrm{cm}$ and filtered before being introduced in the system (filter in line and precolumn-filter). $\delta^{18} \mathrm{O}$ and $\delta^{2} \mathrm{H}$, relative to the Vienna-Standard Mean Ocean Water (RVSMOW), were determined by a Picarro ${ }^{\circ}$ L2130-I Isotopic Water Analyzer (Cavity ring-down laser spectrometer, Picarro Ltd.).

\section{RESULTS}

The DEM created from LiDAR point dataset (Consejería de Medio Ambiente 2008) has permitted to precisely locate the topographic elevation of Aguileras spring emergence: $787.0 \mathrm{~m}$ a.s.l. (Fig. 4), as well as to identify the geometry of all closed depression areas in the western sector of Salinas-Los Hoyos diapir. However, using this dataset it was not possible to establish the topographic altitude of the bottom of Grande Lake, since it was submerged when LiDAR data acquisition was performed (summer 2008). In that moment, water surface in Grande Lake was at $787.7 \mathrm{~m}$ a.s.l, $0.5 \mathrm{~m}$ below Chica. Grande Lake has an overflow channel at its northwest border whose base is located at $795.9 \mathrm{~m}$ a.s.l. (Fig. 4), determining its maximum level of flooding. In comparison with this value, altitude of water surface in Grande Lake was $793.8 \mathrm{~m}$ a.s.l. at the beginning of the recording period considered in the present work and 3.5 meters lower (790.3 $\mathrm{m}$ a.s.l.) at the end.

Tab. 1 presents the most significant statistical parameters corresponding to selected chemical compo-

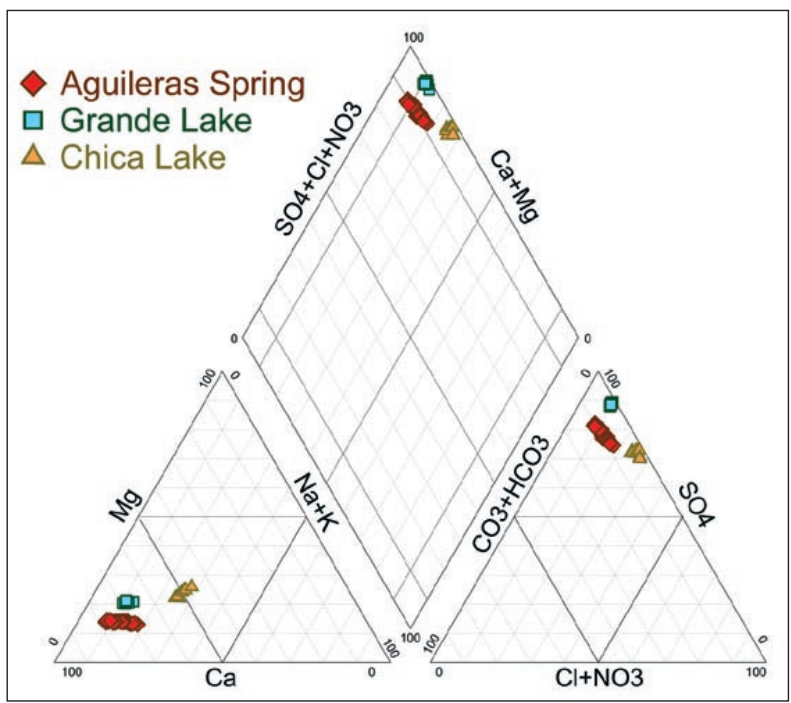

Fig. 5: Piper diagram showing the water samples taken during the study period in the western sector of the Salinas-Los Hoyos Diapir.

Tab. 1: Mean values $(M)$, standard deviation $(\sigma)$ and coefficient of variation $(C V=\sigma / M)$ of spring discharge rate and EC, water temperature, major ion concentrations $(\mathrm{mg} / \mathrm{l})$ and $\delta^{18} \mathrm{O}$ and $\delta^{2} \mathrm{H}$ values (\%o VSMOW) from water samples.

\begin{tabular}{|c|c|c|c|c|c|c|c|c|c|c|c|c|c|c|c|c|c|}
\hline & $\begin{array}{c}N^{\circ} \text { of } \\
\text { samples }\end{array}$ & & $\begin{array}{c}E C \\
(\mathrm{mS} / \mathrm{cm})\end{array}$ & $\begin{array}{c}T \\
\left({ }^{\circ} \mathrm{C}\right) \\
\end{array}$ & $\begin{array}{c}\text { Discharge } \\
(1 / s)\end{array}$ & Alk & $F^{-}$ & $\mathrm{Cl}^{-}$ & $\mathrm{Br}$ & $\mathrm{NO}_{3}^{-}$ & $\mathrm{SO}_{4}^{2-}$ & $\mathrm{Ca}^{2+}$ & $M g^{2+}$ & $\mathrm{Na}^{+}$ & $K^{+}$ & $\delta^{18} 0$ & $\delta^{2} H$ \\
\hline \multirow{3}{*}{$\begin{array}{l}\text { Grande } \\
\text { Lake }\end{array}$} & \multirow{3}{*}{13} & $M$ & 3,43 & 17,4 & - & 65,0 & 0,4 & 201,2 & 1,8 & 2,6 & 2597,7 & 782,8 & 144,1 & 139,1 & 7,3 & 2,19 & $-1,42$ \\
\hline & & $\sigma$ & 0,16 & 7,48 & - & 16,81 & 0,04 & 19,78 & 0,59 & 1,18 & 241,98 & 39,73 & 9,34 & 12,01 & 1,02 & 0,95 & 4,48 \\
\hline & & $\mathrm{CV}$ & 0,05 & 0,43 & - & 0,26 & 0,09 & 0,10 & 0,33 & 0,46 & 0,09 & 0,05 & 0,06 & 0,09 & 0,14 & 0,43 & $-3,16$ \\
\hline Grande & \multirow{3}{*}{5} & M & 3,59 & 14,8 & - & 60,1 & 0,4 & 205,4 & 2,2 & 3,1 & 2676,7 & 788,0 & 155,0 & 138,4 & 6,3 & 3,45 & 4,91 \\
\hline \multirow{2}{*}{$\begin{array}{l}\text { Lake deep } \\
\text { samples }\end{array}$} & & $\sigma$ & 0,01 & 0,13 & - & 0,56 & 0,01 & 1,60 & 0,01 & 0,15 & 23,61 & 7,04 & 1,76 & 1,58 & 0,08 & 0,13 & 0,58 \\
\hline & & $\mathrm{CV}$ & 0,00 & 0,01 & - & 0,01 & 0,01 & 0,01 & 0,00 & 0,05 & 0,01 & 0,01 & 0,01 & 0,01 & 0,01 & 0,04 & 0,13 \\
\hline \multirow{3}{*}{ Chica Lake } & \multirow{3}{*}{13} & M & 4,96 & 15,8 & - & 127,3 & 0,4 & 680,3 & 2,6 & $0, y$ & 2631,4 & 729,3 & 212,3 & 431,2 & 14,0 & 3,77 & 4,76 \\
\hline & & $\sigma$ & 0,54 & 8,19 & - & 37,06 & 0,04 & 108,33 & 0,71 & 1,09 & 288,20 & 61,80 & 35,68 & 60,43 & 1,27 & 1,65 & 7,42 \\
\hline & & $\mathrm{CV}$ & 0,11 & 0,52 & - & 0,29 & 0,09 & 0,16 & 0,28 & 0,28 & 0,11 & 0,08 & 0,17 & 0,14 & 0,09 & 0,44 & 1,56 \\
\hline \multirow{3}{*}{$\begin{array}{l}\text { Aguileras } \\
\text { spring }\end{array}$} & \multirow{3}{*}{47} & M & 2,93 & 16,9 & 29,3 & 274,7 & 0,4 & 192,4 & 1,7 & 15,5 & 1808,4 & 672,4 & 77,0 & 130,1 & 3,5 & $-5,70$ & $-40,36$ \\
\hline & & $\sigma$ & 0,15 & 0,09 & 5,89 & 6,03 & 0,04 & 50,36 & 0,48 & 1,08 & 81,43 & 40,32 & 5,29 & 35,44 & 1,07 & 1,00 & 2,37 \\
\hline & & CV & 0,05 & 0,01 & 0,20 & 0,02 & 0,10 & 0,26 & 0,29 & 0,07 & 0,05 & 0,06 & 0,07 & 0,27 & 0,31 & $-0,18$ & $-0,06$ \\
\hline
\end{tabular}




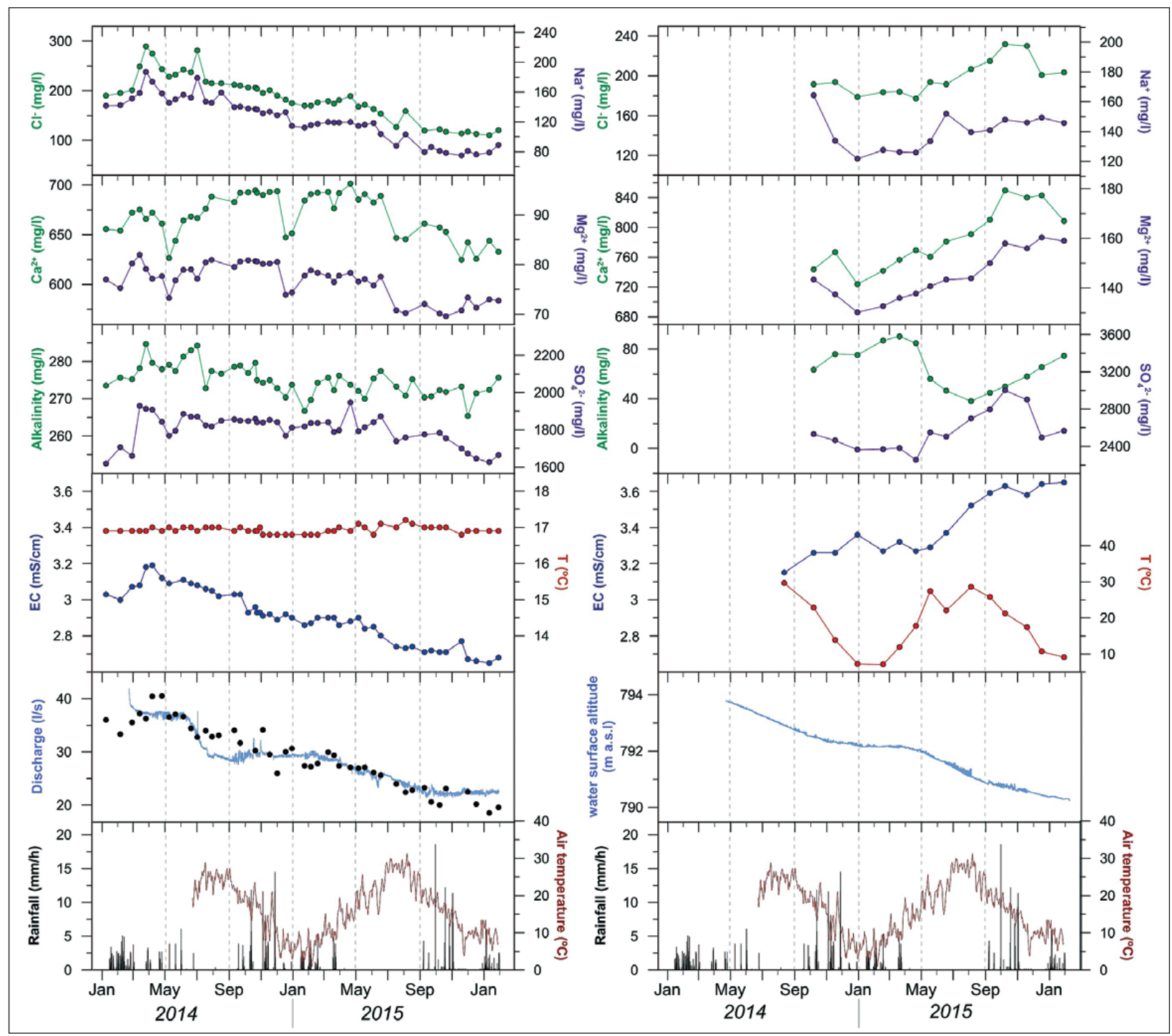

Fig. 6: Temporal evolution of discharge rate, wetland surface altitude, water temperature, EC and major chemical components of the water from Aguileras spring (left) and from Grande Lake (right), respect to daily precipitation events and air temperature variations.

nents and isotopic values of the water stored in Grande and Chica lakes as well as those of the groundwater drained by the Aguileras spring. All present calciumsulphated hydrochemical facies (Fig. 5), according to the prevailing gypsiferous nature of the system rocks. EC values recorded range from 2.65 to $5.78 \mathrm{mS} / \mathrm{cm}$. In general, wetlands waters (especially from Chica) have the highest mean values of all analysed components except for Alkalinity and $\mathrm{NO}_{3}^{-}$. The greatest variations in most of the parameters are observed in the wetlands, although the spring water presents slightly higher coefficient of variation for $\mathrm{Cl}^{-}, \mathrm{Na}^{+}$and $\mathrm{K}^{+}$. Water temperature varied from $7.1^{\circ} \mathrm{C}$ to $30.5^{\circ} \mathrm{C}$ at the wetlands and from 16.8 to $17.2^{\circ} \mathrm{C}$ at Aguileras spring. Finally, mean $\delta^{18} \mathrm{O}$ and $\delta^{2} \mathrm{H}$ values range from $-6.65 \%$ to $6.25 \%$ VSMOW and from $-42.64 \%$ and $16.12 \%$, respectively. The average discharge value from Aguileras spring during the study period was $29.3 \mathrm{l} / \mathrm{s}$.

Fig. 6 shows the variations of water table in Grande Lake and the temporal evolution of discharge (single and continuous measurements) from Aguileras spring, together with EC and water temperature values measured in both, wetland and spring, from January 2014 (from April in the case of Grande Lake) to January 2016; this figure also displays the temporal evolution of most of the major hydrochemical components listed in Tab. 1, together with the rainfall and air temperature recorded in the area for the same time period. Fluctuations in altitude of water surface and in discharge rate were similar, showing a clear descending trend, although less accentuated 


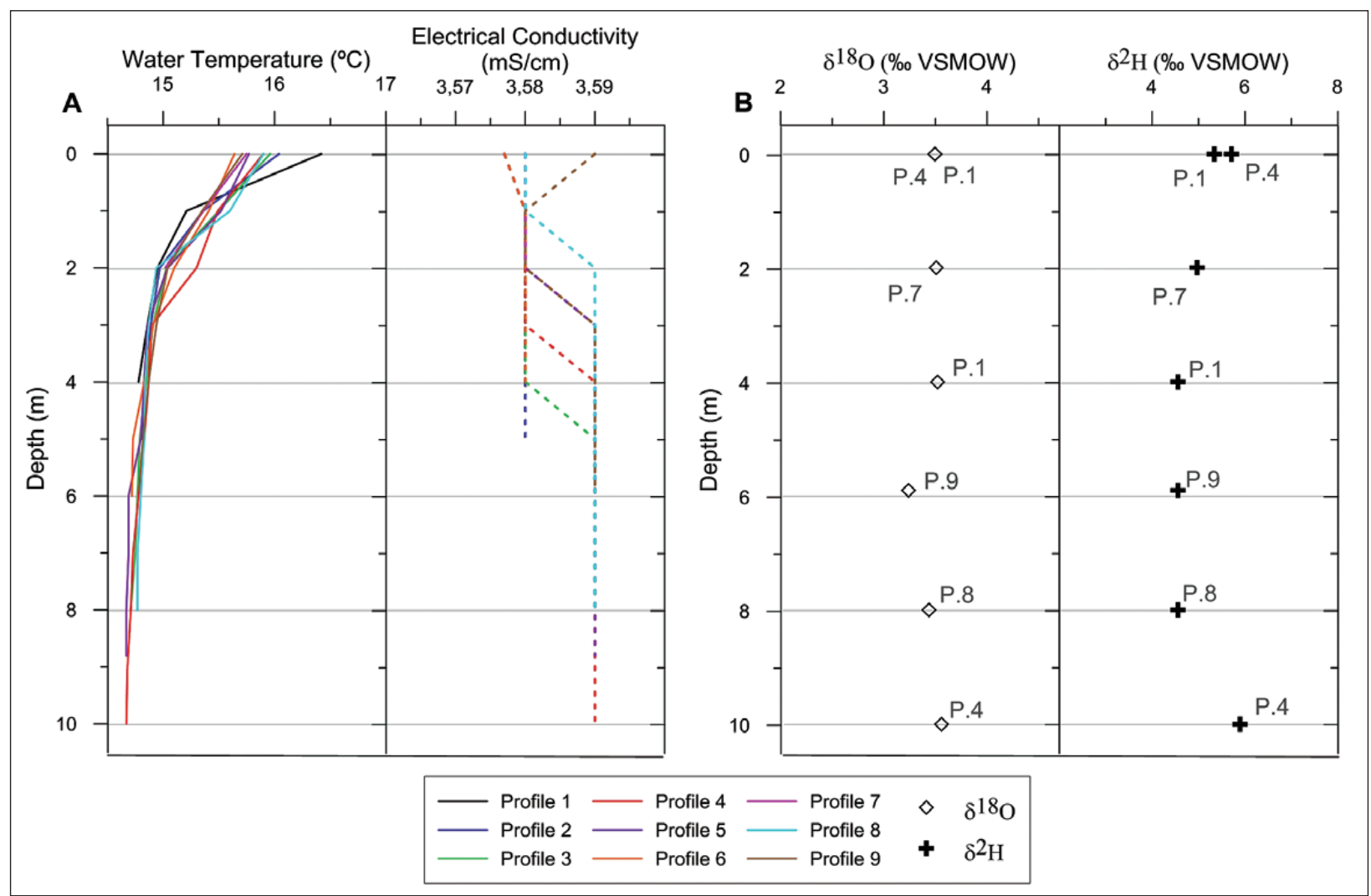

Fig. 7: a) Water temperature (solid line) and EC (dashed line) vertical profiles in Grande Lake. b) Some examples of $\delta^{18} \mathrm{O}$ and $\delta^{2} \mathrm{H}$ isotopic values, from samples taken at different depths and surface at distinct profile measurements (November 2015). The number of the profile in which each plotted samples was taken is indicated (location in Fig. 4).

or even without significant variations, which coincide with the winter months when rainfalls and minimum evaporation occurred. Discharge values ranged from 40.5 to $18.5 \mathrm{l} / \mathrm{s}$, while altitude of water surface varied between 793.8 and $790.3 \mathrm{~m}$ a.s.l. On the contrary, wetland and spring presented different hydrochemical and hydrothermal responses during the study period, certainly opposite in the case of EC. Thus, in the water drained by Aguileras spring there was a general and gradual decrease in EC values, from 3.03 to $2.66 \mathrm{mS} / \mathrm{cm}$, similar to the falling trend observed for the flow rate (Fig. 6). On the other hand, an ascending pattern was found for EC in the water from Grande Lake, from values close to $3.25 \mathrm{mS} / \mathrm{cm}$ to more than $3.60 \mathrm{mS} / \mathrm{cm}$, slightly buffered during recharge periods. These variations in EC, both in spring and wetland, are mainly caused by the corresponding changes in $\mathrm{Cl}^{-}$and $\mathrm{Na}^{+}$contents and, to a lesser extent, in $\mathrm{SO}_{4}^{2-}$ and $\mathrm{Mg}^{2+}$. Finally, Alkalinity in Grande Lake followed a general seasonal variation, so that the highest value was recorded at spring time and the lowest at the end of the summer. With respect to hydrothermal response, water from Aguileras spring presented small changes in temperature $\left(0.4{ }^{\circ} \mathrm{C}\right)$, with recharge having little or no influence on values (Fig. 6), while water tem- perature at Grande Lake, with a greater range of variation $\left(2.15^{\circ} \mathrm{C}\right)$, was clearly influenced by air temperature changes in the area.

The vertical temperature and EC profiles completed in November 2015 along the N-S and W-E axes of Grande Lake (see location in Fig. 4) permitted to observe a common and exponential slight fall in water temperature values, from the wetland surface to the deepest part of each profile (Fig. 7). Hydrothermal variations mainly take place in the first $3 \mathrm{~m}$ of depth, with a general water cooling between 1 and $1.5^{\circ} \mathrm{C}$. However, in the case of water mineralization, no significant changes can be distinguished, only very slight increases of EC values (from 3.58 to $3.59 \mathrm{mS} / \mathrm{cm}$ ), which are produced at the upper part of water columns. Chemical analysis of the water samples taken during the profiles did not show relevant differences between surface and depth water composition. Figure 7 also reveals limited isotopic variations in the vertical, with values ranging from $3.23 \%$ to $3.56 \%$ for $\delta^{18} \mathrm{O}$ and from $4.56 \%$ to $5.89 \%$ or for $\delta^{2} \mathrm{H}$.

In Fig. 8 isotopic data $\left(\delta^{18} \mathrm{O}\right.$ vs $\left.\delta^{2} \mathrm{H}\right)$ collected from rainwater, the spring and Grande and Chica Lakes (including water samples collected at the bottom of Grande Lake during vertical profiles) are represented. From iso- 


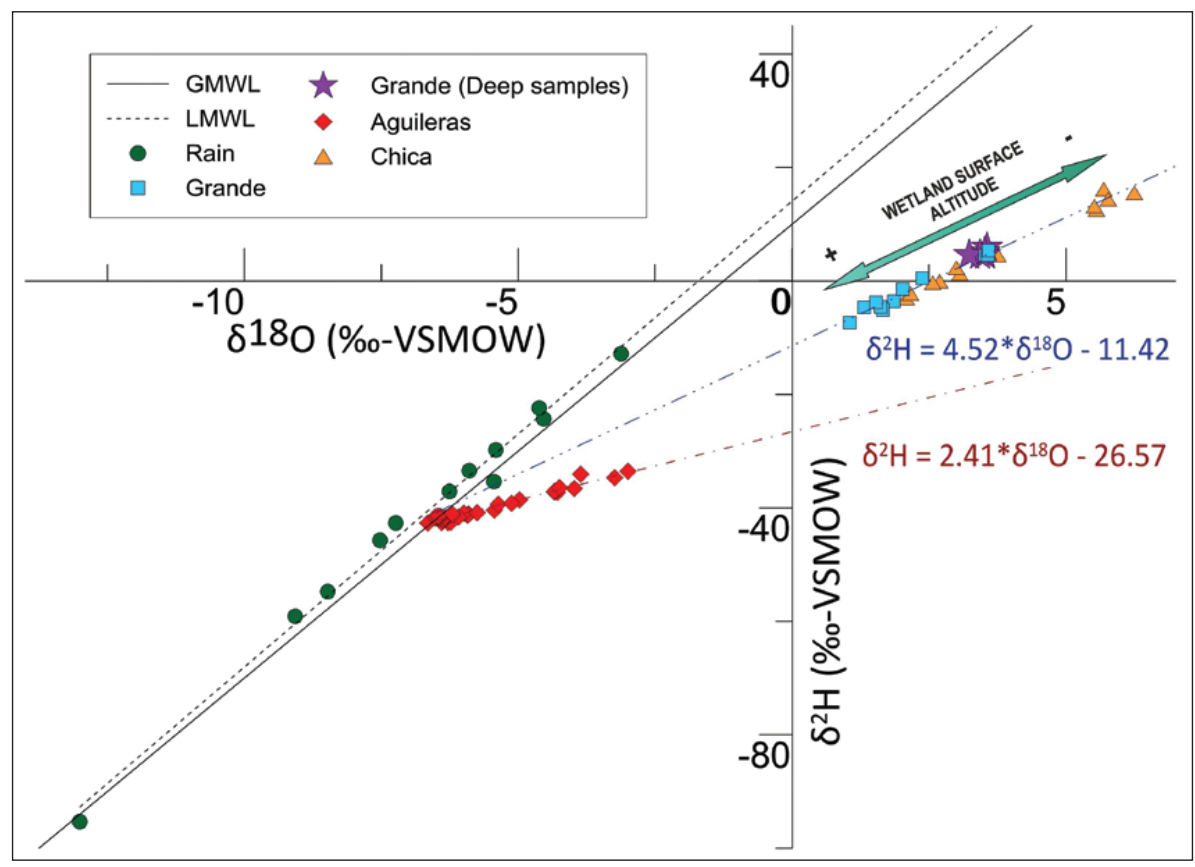

Fig. 8: Isotopic composition of local rain, spring and wetland waters. Global meteoric water line (GMWL) and local meteoric water line (LMWL) are included.

topic determinations of rain water samples, a preliminary local meteoric water line (LMWL) has been calculated for the study area, which is plotted in Fig. 8 together with the global meteoric water line, GMWL (Craig \& Gordon 1965). The isotopic composition of surface water in Grande and Chica Lakes range from $1.06 \%$ to $6.25 \%$ VSMOW for $\delta^{18} \mathrm{O}$ and from $15.58 \%$ to $16.12 \%$ o for $\delta^{2} \mathrm{H}$. Likewise, deep water samples from Grande Lake taken during profile measurements (November 2015) show very slight differences compared to the surficial water samples collected the same day (Fig. $7 \& 8$ ). All of them present isotopic enrichment values and are notably aligned to the right of the GMWL and the LMWL, following an equation (Fig. 8) whose slope (4.52) is lower than those for the meteoric lines. In general terms, the lower the altitude of water surface in lakes is during sam- pling, the higher isotopic enrichment in water exists, reflecting isotopic fractioning processes by direct evaporation of water surface. This is, if possible, more evident in the water of Chica Lake, where greater isotopic enrichment has been detected. Meanwhile, the isotopic composition of groundwater drained by Aguileras spring range from $-6.65 \%$ o to $-3.00 \%$ VSMOW for $\delta^{18} \mathrm{O}$ and from $-42.65 \%$ o to $-33.54 \%$ o for $\delta^{2} \mathrm{H}$ (Tab. 1 ). Most of the samples are fitted to the layout of the meteoric lines (GMWL and LMWL), although some of them have a clear enrichment in $\delta^{18} \mathrm{O}$ in comparison with $\delta^{2} \mathrm{H}$, defining another evaporation line (Fig. 8) with a slope (2.41) lower than that for the surface water. Both evaporation lines converge with LMWL in the same point, which could be considered as an average value of the isotopic composition of the rain water (Fig. 8).

\section{DISCUSSION}

High resolution land elevation data, generated from LiDAR cloud cover, has helped to precisely define the altitude of the different hydrological elements existing in the western sector of Los Hoyos-Salinas system. From this information, the magnitude of the temporal variations in the hydraulic gradient between wetland and spring could be specifically established. Thus, if water surface in the lake reaches $787 \mathrm{~m}$ a.s.l. (spring altitude) or less, no gradient and therefore neither groundwater flow from Grande Lake to Aguileras spring could exist.
As it has been previously mentioned, this spring corresponds to a gallery whose precise emerging point is not accessible to define its exact elevation. Nevertheless, the real outflowing altitude, although slightly higher, should be very similar to this determined in the present work (787 $\mathrm{m}$ a.s.1.).

The total $3.4 \mathrm{~m}$ fall that has been observed in the altitude of wetland surface during the more than 18-month logging period (Fig. 6), between 793.8 and 790.3 m a.s.l., is caused by evaporation outputs but also by fluctuations 
in the water table, produced by a general decrease of precipitation inputs, whose consequences affect the spring discharge as well. The hydrodynamic stability observed in both, the wetland water altitude and the spring discharge rate during rainy months could be indicative of a slowly and lagged system response to recharge events, which would produce an attenuation of general descending trend in phreatic variations. Nevertheless, such stabilization could also be related to a decrease in evaporation outputs or, more likely, to a combination of both processes. In any case, during the study period, water surface of wetland was always located at higher position than the altitude of the spring and, therefore, groundwater flows from the first towards the second could exist. In May 2006, after several years of drought, altitude of the water surface in Grande Lake was found several meters below the position of the Aguileras spring (RodríguezRodríguez et al. 2007).

The increment of EC values observed in wetland surface (Fig. 6) during the study period is mainly due to a general concentration of dissolved ions in water because of evaporation, simultaneously to the isotopic fractioning, which is accentuated at the surface of the water column during the summer months. Considering that stratification is produced in Grande Lake in summer (Rodríguez-Rodríguez et al. 2007), surface measurements could not be representative of the water lake as whole. However, data from vertical EC and water temperature profiles (Fig. 7), carried out in November 2015 , as well as the chemical and isotopic determination of samples at different depths, do not reveal significant variations among surface and deep water, beyond temperature changes in the first few meters (due to the influence of air temperature). In fact, during sampling campaign, surficial water temperature decreased $0.5^{\circ} \mathrm{C}$ from the first measurement $(03: 00 \mathrm{pm})$ to the last one $(06: 00 \mathrm{pm})$. This difference in an approximately 3 hours interval suggests that higher variations are possible throughout the day and, therefore, water at the surface could be cooled down to the same temperature as depth or even more, which would propitiate the mixing of the water column towards the end of the night or the early morning. This interpretation could explain the chemical and isotopic homogeneity of the water column when the vertical profile measurements were carried out. Nevertheless, it would be necessary to repeat the procedure several times along the year, especially during the summer, in order to check this hypothesis. In any case, water body as a whole could be considered hydrochemically homogenous (Rodríguez-Rodríguez et al. 2007).

Despite the increasing trend in water mineralization of Grande Lake, this does not seem to have any influence on the groundwater drained by Aguileras spring. On the contrary, EC of spring water fell during the study period (Fig. 6). Variations in salinity of spring water mostly derived from changes in the dissolution rate of the evaporitic rocks (gypsum and halite), which constitutes the core of diapiric structure. During significant recharge events, such as that at the beginning of the control period, an increase in outflow rate was accompanied by a sympathetic rise in water mineralization and in the components that most affect it $\left(\mathrm{SO}_{4}^{2-}, \mathrm{Cl}^{-}\right.$and $\left.\mathrm{Na}^{+}\right)$, which took place in a moderate and buffered way during few months. Nevertheless, when the main recharge effects finished (toward dry conditions), water drained by the spring became less saline as discharge decreased, reflecting a general piezometric recession into the system. In other words, if recharge events are sufficiently relevant, they are able to involve the entire system, causing a delayed piston effect that pushes water previously stored within the saturated zone towards the spring; this water is characterized by a bigger residence time within the aquifer, greater $\mathrm{EC}$ and higher contents of $\mathrm{SO}_{4}^{2-}, \mathrm{Cl}^{-}$and $\mathrm{Na}^{+}$. On the contrary, if piezometric level decreases, influence of piston effect gradually disappears and the more mineralized water sinks down due to its higher density, leading to an internal stratification of groundwater into the system.

The increasing evaporation rate at the beginning of summer would produce an increment of most of the dissolved ion concentrations in Grande Lake waters (Fig. 6). On the other hand, the descent of Alkalinity observed in the same period indicates that calcite precipitation was taking place, not only due to evaporation but also to the effect of temperature in its solubility and to common ion effect (Calaforra \& Pulido-Bosch 1993; Ford \& Williams 2007). Thus, the higher presence of $\mathrm{Ca}^{2+}$ in the lake waters, as a result of gypsum dissolution, would favor the oversaturation in calcite and, therefore, its precipitation. Additionally, the concentrations of $\mathrm{NO}_{3}^{-}$in the waters of both wetlands, lower than in the groundwater drained through Aguileras spring (Tab. 1), may be a result of denitrification.

The isotopic composition of Aguileras spring and of the surficial waters of Grande and Chica lakes show clear evidences of evaporation fractioning, although the isotopic values differ depending on the origin of the samples. In the case of wetlands, deviations from GMWL and LMWL define an evaporation line with a slope value between 4 and 6 (Fig. 8), typical of free surface waters directly exposed to the atmosphere (Mook 2001). The isotopic enrichment in Chica Lake is higher than the observed for Grande, since lower flooded area and water column exist at the first one and, thus, evaporation effect is accentuated in its waters. Likewise, as the wetland flooding surface and consequently their water column were diminishing, the isotopic composition of their waters became more enriched in heavy isotopes. 
Although groundwater samples from the spring are closer to the meteoric water, they also present some isotopic fractioning (mainly $\delta^{18} \mathrm{O}$ ), defining a regression line with a slope smaller than 4 , which could be associated to evaporation processes within the subsoil (Geyh et al. 2001). However, the marked exo and epikarst development in Los Hoyos-Salinas diapir would be consistent with a relatively high infiltration rate and, therefore, with an important role of unsaturated zone in the hydrogeological functioning of the system. Under this scenario, most of recharge water (overall fast infiltration) does not undergo significant evaporation processes because it flows rapidly toward the saturated zone via karst conduits. In opposition, water inputs by slow diffuse infiltration through massive gypsum outcrops and polygenic breccia can be stored in the soil and epikarst, and within the fractures of the unsaturated zone (dissolving gypsum minerals), where several cycles of evaporation processes could affect groundwater, before it is being pushed toward the saturated zone. Hence, isotopic information from Aguileras spring reveals a mixing between more rapidly infiltrated water (via sinkholes) and the recharge water stored in the soil and epikarst, which circulates slowly through the unsaturated zone, demonstrating the heterogeneous hydrogeological functioning of this system.

Although wetland and spring waters have undergone evaporation process, it seems probable that such processes would have occurred in different sectors of the system. Therefore, it is not possible to assume, with the available isotopic data, the contribution of wetlands water to spring flow. Rodríguez-Rodríguez et al. (2006, 2007) carried out several isotopic determinations of both water points between April 1992 and April 1994. Results already reflected clear differences between $\delta^{2} \mathrm{H}$ and $\delta^{18} \mathrm{O}$ values from wetland and spring. Nevertheless, no isotopic fractioning was observed for Aguileras water samples. Results of this work suggest that waters drained by the spring could also have been affected by evaporation at a certain time. Thus, given the hydrogeological complexity of the system, greater isotopic variability in groundwater could be expected, overall under different climatic conditions.

The analysis of all information here presented (topographic, hydrodynamic, hydrochemical and isotopic) does not permit to discern the degree of hydrogeological connection between the wetlands (especially Grande Lake) and the Aguileras outflow point. Isotopic and hydrochemical responses do not suggest a clear hydrogeological connection conversely to the temporal evolution of hydrodynamic response, as well as to the topographical altitude. In any case, it is premature to assume any hypothesis if the hydrogeological functioning of the system is not fully understood in detail yet, and also without data from a longer study period. Nevertheless, preliminary results reveal that the system is complex and has a high capacity of natural regulation, in which both unsaturated and saturated zones might play relevant roles.

\section{CONCLUSION}

Results obtained in this work allow deducing preliminary conclusions about the hydrological and hydrogeological functioning of the western sector of the evaporitic system of Los Hoyos-Salinas diaper (Malaga province, South Spain), during a period of low precipitation, in which water levels underwent a general decreasing trend. In this context, it has not been possible to confirm the existence of direct groundwater flows from Grande Lake towards Aguileras spring, from the hydraulic point of view. This hypothesis would make sense if the water table in the wetland is higher than the spring emerging altitude, which is common during high and intermediate water conditions. Thus, for better understanding of hydrogeological behavior, a longer monitoring period should be recorded, comprising maximum and minimum flooding episodes. This would permit to deduce the hydrogeological functioning of the system and to determine precisely the direction and evolution of groundwater flows.
The wetland-groundwater interaction in Grande and Chica lakes is not an isolate case. On the contrary, it is fairly common in Andalusia region and especially in many wetlands related to CSC outcrops. The continuous limnimetric control of those areas, together with the analysis of the natural responses recorded in associated springs, provide valuable information about their hydrological and hydrogeological contexts. Furthermore, LiDAR cover datasets are useful tools to precise wetland depressions shapes, which combined with limnimetric measurement may allow to calculate, in further studies, the variation of water volume stored in wetlands and, therefore, to accurately determine their water budgets.

Due to its peculiarities (from a geomorphological, hydrogeological, ecological and landscaping point of view), the Los Hoyos-Salinas diapiric structure is an exceptional example of evaporitic karst system. Therefore, special protection and correction actions (beyond the ecological ones), should be applied in order to reduce 
anthropogenic impacts and pressures, especially taking into consideration the high vulnerability of gypsum karst. Furthermore, the inclusion of Los Hoyos-Salinas diapir in the Spanish List of Geosites must be consid- ered, as an example of evaporite karst system where different geomorphological and structural elements can be observed (diapirism, dolines, sinkholes, swallow holes, etc).

\section{ACKNOWLEDGMENT}

This work is a contribution to IGCP-598 project of UNESCO, to the Excellence Projects RNM-8087 and
RNM-6895-R of Junta de Andalucía and to the Research Group RNM-308 of the Junta de Andalucía.

\section{REFERENCES}

Almécija, C., 1997: Estudio hidrológico e hidroquímico de los sistemas lagunares del norte de la provincia de Málaga.- $\mathrm{PhD}$ thesis. University of Granada, pp. 518.

Andreo, B., Carrasco, F., Durán, J.J., Jiménez, P. \& J.W. LaMoreaux (eds.), 2015: Hydrogeological and enviornmental investigations in karst systems.- Springer, pp. 638, Heidelberg.

Andreo, B., Gil-Márquez, J.M., Mudarra, M., Linares, L. \& F. Carrasco, 2016: Hypothesis on the hydrogeological context of wetland areas and springs related to evaporitic karst aquifers (Málaga, Córdoba and Jaén provinces, Southern Spain).- Environmental Earth Sciences, 75, 9, 1-19. doi:10.1007/s12665-016 $-5545-1$

Calaforra, J.M., 1998: Gypsum karstology.- Monografías Ciencia y Tecnología, University of Almeria-Instituto de Estudios Almerienses, pp. 384, Almeria, Spain.

Calaforra, J.M. \& A. Pulido-Bosch, 1993: The hydrochemistry and morphology of the triassic gypsum in the Salinas-Fuente Camacho Area (Granada).- In: Pulido-Bosch, A. (ed.) Some Spanish Karstic Aquifers. University of Granada, pp. 387-389, Granada.

Calaforra, J. \& A. Pulido-Bosch, 1999: Gypsum karst features as evidence of diapiric processes in the Betic Cordillera, Southern Spain.- Geomorphology, 29, 3-4, 251-264.

Carrasco F., 1986: Contribución al conocimiento de la cuenca alta del río Guadalhorce. El medio físico. Hidrogeoquimica.- PhD thesis. University of Granada, pp. 435.

Carrasco, F., Durán, J.J. \& J.M. Calaforra, 2007: El Trías de Antequera.- In: Durán, J.J. (ed) Atlas hidrogeológico de la provincia de Málaga. Instituto Geológico y Minero de España, Diputación de Málaga, pp. 206-210, Madrid.
Consejería de Medio Ambiente (ed.), 2005: Contexto hidrogeológico de humedales andaluces, 7 issues.EGMASA-Grupo de Hidrogeología de la Universidad de Málaga, unpublished report.

Consejería de Medio Ambiente, 2008: Nubes de puntos LiDAR Cuencas Guadalhorce-Guadiaro, 2008.Consejería de Agricultura, Pesca y Medio Ambiente. Junta de Andalucía.

Cooper, A.H. \& F. Gutiérrez, 2013: Dealing with gypsum karst problems: hazards, environmental issues, and planning.- In: Frumkin, A. (Ed.) Treatise on Geomorphology. Vol. 6, Karst Geomorphology, Academic Press, pp. 451-462, San Diego, CA.

Craig, H. \& L.I. Gordon, 1965: Deuterium and oxygen18 variations in the ocean and the marine atmosphere.- In: Tongiorgi E (ed) Proceedings of a Conference on Stable Isotopes in Oceanographic Studies and Paleotemperatures. Spoleto, Italy, 9-130, Italy.

Drew, D. \& N. Goldscheider (eds.), 2007: Methods in Karst Hydrogeology.- Taylor \& Francis/ Balkema, pp. 264, London.

European Commission, 1995: Hydrogeological aspects of groundwater protection in karstic areas.- European Commission, Report EUR 16547 EN.

Ford, D.C. \& P.W. Williams, 2007: Karst Geomorphology and Hydrology.- John Wiley \& sons, pp. 576, London.

Forti, P. \& U. Sauro, 1996: The gypsum karst of Italy.- International Journal of Speleology, 25, 3-4, 239-250.

Geyh, M., D’amore, F., Darling, G., Paces, T., Pang, Z. \& J. Silar, 2001: Environmental Isotopes in the hydrological cycle. Principles and applications.- IHP-V Technical Documents in Hydrology, No 39., Vol. IV, UNESCO - IAEA, pp. 413, Paris. 
Gutiérrez, F., Calaforra, J.M., Cardona, F., Ortí, F., Durán, J.J. \& P. Garay, 2008: Geological and environmental implications of the evaporite karst in Spain.- Environmental Geology, 53, 5, 951-965. doi:10.1007/ s00254-007-0721-y

Gutierrez F., Parise M., De Waele J. \& Jourde H., 2014: A review on natural and human-induced geohazards and impacts in karst.- Earth Science Reviews, 138: 61-88

Iovine G., Parise M. \& Trocino A., 2010: Breakdown mechanisms in gypsum caves of southern Italy, and the related effects at the surface.- Zeitschrift fur Geomorphologie, vol. 54 (2): 153-178.

Klimchouk, A., Forti, P. \& A. Cooper, 1999: Gypsum karst of the World: a brief overview.- International Journal of Spelology, 25, 3-4, 159-181.

Ligouri, V., Manno, G. \& D. Mortellaro, 2008: Evaporite karst in Sicily.- Environmental Geology, 53, 975980.

Linares, L., 2004: Lagunas de Fuente de Piedra y Archidona.- In: Nuche, R., Durán, J.J. \& M. Vallejo (eds.) Patrimonio Geológico de Andalucía. ENRESA, pp. 466-473, Sevilla.

Linares, L., 2008: Lagunas y humedales andaluces relacionados con surgencias.- In: A. Castillo (ed.) Manantiales de Andalucía. Agencia Andaluza del Agua, Consejería de Medio Ambiente, Junta de Andalucía, pp.156-171, Sevilla.

López-Chicano, M., Bouamama, M., Vallejos, A. \& A. Pulido-Bosch, 2001: Factors which determine the hydrogeochemical behaviour of karstic springs. A case study from the Betic Cordilleras, Spain.- Applied Geochemistry, 16, 1179-1192.

Martos-Rosillo, S., Rodríguez-Rodríguez, M., Pedrera, A., Cruz-San Julián, J.J. \& J.C. Rubio, 2013: Groundwater recharge in semi-arid carbonate aquifers under intensive use: the Estepa Range aquifers (Seville, southern Spain).- Environmental Earth Sciences 70, 6, 2453-2468. doi:10.1007/s12665-013-2288-0

Mook, W.G., 2001: Environmental Isotopes in the hydrological cycle. Principles and applications.- IHP-V Technical Documents in Hydrology, No 39., Vol. I, UNESCO - IAEA, pp. 413, Paris.

Nicod, J., 2006: Lakes in gypsum karst: Some examples in alpine and mediterranean countries.- Acta Carsologica, 35, 1, 69-78.

Parise, M., De Waele, J. \& F. Gutierrez, 2008: Engineering and environmental problems in karst - An introduction.- Engineering Geology, 99, 3-4, 91-94.
Pérez-López, A. \& C. Sanz de Galdeano, 1994: Tectónica de los materiales triásicos en el sector central de la Zona Subbética (Cordillera Bética).- Revista de la Sociedad Geológica de España, 7, 141-153.

Peyre, Y., 1974: Géologie d'Antequera et de sa región (Cordilleres Bétiques, Espagne).- $\mathrm{PhD}$ thesis. Inst. Agr. Paris, pp. 528.

Pezzi, M.C., 1977: Morfología kárstica del sector central de las cordilleras Subbéticas.- PhD thesis. University of Granada, pp. 450.

Pineda Velasco, A., 1990: Hoja 1024 (Archidona). Mapa Geológico de España 1:50.000.- Madrid.

Rodríguez-Estrella, T., 1983: Neotectónica relacionada con las estructuras diapíricas en el Sureste de la Península Ibérica.- Tecniterrae, 51, 14-30.

Rodríguez-Fernández, J., Roldán, F.J., Azañón, J.M. \& A. García-Cortés, 2013: El colapso gravitacional del frente orogénico alpino en el Dominio Subbético durante el Mioceno medio-superior: El Complejo Extensional Subbético.- Boletín Geológico y Minero, 124, 3, 477-504.

Rodríguez-Rodríguez, M., Benavente, J., Cruz-San Julián, J.J. \& F. Moral Martos, 2006: Estimation of ground-water exchange with semi-arid playa lakes (Antequera region, southern Spain).- Journal of Arid Environments, 66, 272-289.

Rodríguez-Rodríguez, M., Moral, F. \& J. Benavente, 2007: Hydro-morphological characteristics and hydrogeological functioning of a wetland system: A case study in southern Spain.- Environmental Geology, 52, 7, 1375-1386.

Sanz de Galdeano, C., Lozano, J.A. \& E. Puga, 2008: El "Trías de Antequera": naturaleza, origen y estructura.- Revista de la Sociedad Geológica de España, 21, 110-124.

Thornthwaite, C.W., 1948: An approach toward a rational classification of climate.- Geographical Review, 38, 1, 55-94. doi:10.2307/210739

Vera, J.A. \& A. Martín Algarra 2004: Cordillera Bética.In: Vera, J.A. (ed.) Geología de España. IGME-Sociedad Geológica de España, pp. 345-464, Madrid.

White, W.B., 1988: Geomorphology and hydrology of karst terrains.- Oxford University press, pp. 464, New York. 